\title{
Ф.А. МИР-БАГИРЗАДЕ
}

\section{ОРИЕНТАЛЬНАЯ СИМВОЛИКА БАЛЕТА «СЕМЬ КРАСАВИЦ» ПО МОТИВАМ ПОЭМЫ НИЗАМИ ГЯНДЖЕВИ}

\begin{abstract}
Ключевые слова: Низами Гянджеви, архетип, ориентализм, хореографрическое искусство, балет, «Пятерица», художественный образ, метафрора в искусстве, сценография, искусство ашугов, Кара Караев.
\end{abstract}

Автор исследует творческие интерпретации произведения поэтагуманиста Низами Гянджеви (XII в.) из цикла «Хамсе» «Семь красавиц». Поэт был подлинным эрудитом, знатоком не только коранических текстов, истории, античной и мусульманской фрилософрии, но и астрономии. Данная статья - попытка проследить ориентальную символику образов Гянджеви в одной из творческих интерпретаций поэмы «Семь красавищ» через призму хореографрического и сценографического искусства. Метод исследования - семиотический анализ, объект исследования - балет «Семь красавищ», объединивший достижения современной европейской хореографии и средневековую восточную поэзию с присущей ей образностью, поставленный на музыку азербайджанского композитора Кара Караева. Композитор К. Караев активно использовал самобытные музыкальные традиции Азербайджана (музыкальные гармонии, мелодика ашугов и элементы народных азербайджанских ладов), сочетая их с европейскими мелодиями и ритмами. Анализируя фольм-балет «Семь красавиц» (1982, режиссер Феликс Слидовкер) и новую постановку театра оперы и балета имени М.Ф. Ахундова (2011), автор прослеживает трансформацию либретто и предлагает собственное прочтение символики метафоричного произведения классика Низами Гянджеви. Поиски истины, красоты и справедливости всегда были уделом мыслящего человека. Восточные поэты воспевали этот поиск, этот долаий и трудный путь к истине, идеальному миру. Придворные интриги, роскошь двориа и повседневная жизнь простого народа, благородство, коварство и любовь переплелись в этой метафоричной восточной притче, которая легла в основу нескольких интерпретаций балета «Семь красавиц». Несмотря на большую степень условности, свойственной этому жанру сценического искусства, фильм-балет характеризуется драматургической многоплановостью, органическим сплетением развивающихся сюжетных линий, динамической взаимосвязью социального и лирикопсихологического конфрликтов. Трансформация либретто балета «Семь красавиц» свидетельствует о новом, более глубоком прочтении, приближении его к идейно-фрилософрской метафоричной концепции оригинальной поэмы Низами Гянджеви, воспетому поэтом вечному поиску истины, любви и справедливости со свойственной ему ориентальной образностью.

Произведение «Хамсе», или «Пятерица», принадлежащее перу писавшего по-персидски поэта-гуманиста Низами Гянджеви (XIIв.), хорошо известно читателю. Поэт, родившийся в Гяндже, был подлинным эрудитом, знатоком не только коранических текстов, истории, античной и мусульманской фрилософиии, но и астрономии. Эти разносторонние знания, в том числе платоновская идея идеального государства, натурфилософское представление о связи известных тогда семи планет с соответствующими стихиями, металлами, днями недели, цветами спектра и т.п., которое позже было заимствовано европейскими алхимиками, а также фрольклорные тексты в 1197 г. легли в основу одной из поэм сборника «Пя- 
терица», получившей название «Семь красавиц». В мировоззрении, социальных и этических взглядах Низами исследователи видят черты, которые обычно ассоциируются с культурой эпохи Возрождения [1. С. 6].

Ставшее классикой наследие Низами Абу Мухаммеда Ильяса ибн Юсуфра (таково полное имя поэта) обширно, а его влияние на поэтику, литературу и искусство Азербайджана столь велико, что его еще предстоит осмыслить.

Данная статья - попытка проследить ориентальную символику образов Гянджеви в одной из творческих интерпретаций поэмы «Семь красавиц» через призму хореографического и сценографического искусства. В середине XX в. по мотивам произведения великого средневекового поэта был поставлен балет «Семь красавиц», объединивший достижения современной европейской хореографии и средневековую восточную поэзию с присущей ей образностью. На такую амбициозную задачу решился азербайджанский композитор Кара Караев, еще в 1949 г. создавший симфоническую сюиту по мотивам поэмы Низами (800летний юбилей со дня рождения поэта-гуманиста торжественно и широко отмечался в СССР). Либретто подготовили С. Рахман, И. Идаятзаде и Ю. Слонимский, а сам балет, премьера которого состоялась в Азербайджанском театре оперы и балета имени М.Ф. Ахундова (Баку) в ноябрьские праздники 1952 г., поставил балетмейстер П.А. Гусев. Именно в этом прочтении балет с успехом обошел сцены Москвы, Ленинграда, многих советских и зарубежных театров.

Партитуру К. Караева, «блестяще оркестрованную» [3. С. 10], подлинно симфоническую, «обладающую масштабностью, широким дыханием», высоко оценил Д.М. Шостакович [7. С. 12]. Важно, что композитор Кара Караев «не пошёл по пути музыкально-хореографической иллюстрации сюжетов Низами - он поставил перед собой задачу создания произведения иного жанра, произведения, имеющего самостоятельную идейно-художественную концепцию», добившись «выражения значительных по своей гуманистической силе идей и многогранных чувств средствами именно балетной музыки» [5. С. 170-171]. Композитор К. Караев активно использовал самобытные музыкальные традиции Азербайджана (музыкальные гармонии, мелодика ашугов и элементы народных азербайджанских ладов), сочетая их с европейскими мелодиями и ритмами [7. С. 14].

В начале 1980-х гг. популярный у зрительской аудитории балет было решено снять на кинопленку, так в 1982 г. режиссер Ф. Слидовкер снял на музыку К. Караева одноименный фрильм-балет, где сценаристами выступили М. и Р. Ибрагимбековы, авторами либретто и хореографами - Р. Ахундова и М. Мамедов, художниками-постановщиками - А. Магерамов, Р. Насиров, Э. Рзакулиев. Выстроенный мизансценический рисунок, в котором роль актёров на сцене балета, их пластические возможности создавали модуль пространства театральной сцены. Сценографическое решение балета «Семь красавиц» находится в контексте драматического диалога и постоянно испытывает его влияние. Зритель смотрит и слушает фильм-балет одновременно: услышанное влияет на зрительное восприятие, взгляд акцентируется на определенных сценических деталях и заставляет по-новому отнестись к произнесенному тексту. Фильм-балет характеризуется драматургической многоплановостью, органическим сплетением развивающихся сюжетных линий, динамической взаимосвязью социального и лирико-психологического конфликтов.

Для композитора и авторов либретто гуманистические идеи поэта и мыслителя Низами были важнее строгого следования фабуле поэмы. Балетовед Юрий Иосифович Слонимский отмечал: «Избрана генеральная тема творчества Низами - его размышления о судьбе азербайджанского народа его времени, о Человеке с большой буквы, борющемся против бесчеловечности 
средневековья, против порабощения народа. Судьба человеческая - судьба народная, - эта фрормула лежит в основе музыкально-сценического действия» [4. С. 18-19]. Именно поэтому в хореографическую и сюжетную ткань балета «Семь красавиц» без лишней назидательности и иносказательности вплетены нити повествования других произведений средневекового поэта из Гянджи («Лейли и Меджнун», «Хосров и Ширин» с параллелями образов Айши и Ширин, «Сокровищница тайн»). Акцент на социальном, а не на филлсофском прочтении произведения диктовался советской эпохой, именно поэтому композитор и авторы либретто сделали главным героем не Айшу, не Бахрама, а народ, который способен решать свою судьбу.

Жанровое определение балета, данное искусствоведами, - музыкальнохореографическая трагедия романтического плана [3. С. 10]. Придворные интриги, роскошь дворца и повседневная жизнь простого народа, благородство, коварство и любовь переплелись в этой метафоричной восточной притче.

Сюжетная линия произведения Низами, воспроизведенная в танце, вкратце такова: шах Бахрам влюбляется в простую девушку Айшу, которая не может похвастаться аристократическим происхождением, но прекрасна душой и телом, но она отвергает его любовь: полюбив Бахрама-охотника, Айша разочаровывается в Бахраме-правителе [7. С. 22].

Жестокий правитель бросил в тюрьму брата гордой красавицы Мензера, обрек свой народ на голод и страдания. В произведении Низами астролог предсказывает Бахраму появление в его жизни семи красавиц из разных стран, каждая из которых символизирует планету, цвет, климатический пояс, день недели и т.д. Например, понедельник и зеленый цвет ассоциировался у Низами с девушкой из Хорезма и Луной, которую в ту пору считали планетой, как и Солнце; вторник и красный цвет (Марс) - с юной славянкой; среда и бирюза (Меркурий) с девой из Магриба; четверг и сандал (Юпитер) - с дочерью Византии; священная для мусульман пятница и белый цвет (Венера) - с персидской красавицей; суббота и черный цвет (Сатурн) - с девой из Индии, а воскресенье и желтое Солнце - с прекрасной дочерью Поднебесной империи. Коварный визирь пытается отвлечь своего господина воспоминаниями о семи призрачных красавицах, но вместо них перед Бахрамом предстают семь посланцев народа и Айша, они требуют, чтобы он покинул страну. Разгневанный шах смертельно ранит девушку. Народ прощается с Айшой и изгоняет Бахрама.

В 2011 г. в Баку на прославленной сцене театра оперы и балета имени М.Ф. Ахундова балет «Семь красавиц» был поставлен вновь. Изменилось и либретто, и цветовая символика [6].

Отважный и ловкий правитель Бахрам однажды на охоте попадает в пещеру, где видит фреску с семью красавицами. Семь дивных видений манят за собой и обещают неведомое счастье. Бахрам пытается рассмотреть их, и ему это удается, лишь самая загадочная красавица в белом одеянии Прекраснейшая - ускользает. Бахрам решает найти загадочных девушек, выстроить для них дворец и обрести счастье. Идут годы, и шесть красавиц прибывают к шаху Бахраму. Встреча с первой, индийской, красавицей не приносит покоя - любовь его окрашена в черный цвет печали. Вторую ночь шах Бахрам проводит с хорезмской красавицей в ее красных покоях. Страсть Бахрама оборачивается разочарованием и гневом. В чудесном зеленом саду принцесса из Поднебесной пытается научить Бахрама видеть гармонию мира природы. С ней он становится мудрее и спокойнее, но и равнодушнее. Его по-прежнему манит призрачный образ царевны в белом. В золотых дворцовых покоях ждет шаха магрибинская принцесса, предла- 
гающая шаху не только золото, но и алхимическую саламандру, олицетворяющую вечную жизнь. Не находит Бахрам свою мечту и в голубых покоях славянской царевны. Лишь царевна в белом, Прекраснейшая, может подарить мятущемуся правителю счастье: белый, цвет вне спектра, олицетворяет добро, истину, чистоту, мудрость, божественный свет. Бахрам в одиночестве отправляется в пустые белые покои дворца и видит там призрак своей таинственной возлюбленной [6]. Расследовав преступления коварного визиря, Бахрам восстанавливает справедливость и порядок в своей стране [2. С. 224]. Отправившись на свою последнюю охоту, шах снова видит призрачных красавиц, чудесных в своей недостижимости. Бахрам решает отречься от престола и соединиться со своей мечтой. Но иллюзии рассеиваются, семь призрачных принцесс покидают шаха.

Поиски истины, красоты и справедливости всегда были уделом мыслящего человека. Восточные поэты воспевали этот поиск, этот долгий и трудный путь к истине, идеальному миру. Сюжет каждой новеллы поэмы Низами Гянджеви - особое любовное переживание, причем, восходя от черного к белому, чувственность превращается в духовную любовь. Восхождение от мрака к чистоте меняет самого Бахрама: из легкомысленного юного царевича он становится справедливым и умным правителем.

Трансформация либретто балета «Семь красавиц» свидетельствует о новом, более глубоком прочтении, приближению его к идейно-фрилософрской метафоричной концепции оригинальной поэмы Низами Гянджеви, воспетому поэтом вечному поиску истины, любви и справедливости со свойственной ему ориентальной образностью.

\section{Литература}

1. Бонч-Осмоловская Е.К. Балеты Кара Караева «Семь красавиц» и «Тропою грома». М.: Советский композитор, 1961. 89 с.

2. Додхудоева Л.Н. Поэмы Низами в средневековой миниатюрной живописи. М.: Наука, 1985. 310 с.

3. Карагичева Л.В. Кара Караев. М.: Советский композитор, 1960, 298 с.

4. Максов А. У врат царства // Линия. Журнал «Балет» в газетном формате. 2011. № 4-5. C. 18-19.

5. Медведев В.М. Балет Кара Караева «Семь красавиц». Проблема традиций и обновления // Вестник Академии русского балета имени А.Я. Вагановой. 2010. № 1(23). С. 169-175.

6. Темиз Я. Либретто «Семь красавиц» [Электронный ресурc]. URL: https://iri-infballet.livejournal.com/167446.html (дата обращения: 05.10.2020).

7. Фахрадова Р. Балет «Семь красавиц» К. Караева. Баку: Азербайджанское государственное музыкальное изд-во, 1957. 68 с.

МИР-БАГИРЗАДЕ ФАРИДА АЛТАЙ КЫЗЫ - кандидат искусствоведения, доцент по эстетике, ведущий научный сотрудник отдела «Изобразительные, декоративно-прикладные искусства и геральдика», Институт архитектуры и искусства Национальной Академии наук Азербайджана, Азербайджан, Баку (faridamb2013@gmail.com).

Farida ALTAI MIR-BAGIRZADE

ORIENTAL SYMBOLISM OF THE BALLET "SEVEN BEAUTIES" BASED ON THE POEM BY NIZAMI GANJAVI

Key words: Nizami Ganjavi, archetype, orientalism, choreographic art, ballet, "Pyateritsa", artistic image, metaphor in art, scenography, Ashug art, Kara Karaev. 
The author explores creative interpretations of the work "Seven Beauties" written by a humanist poet Nizami Ganjavi ( $7^{\text {th }}$ century) from the "Hamse" cycle. The poet was a genuine erudite, connoisseur of not only Koranic texts, history, ancient and Muslim philosophy, but astronomy as well. This article is an attempt to trace the oriental symbolism in the images of Ganjavi in one of the creative interpretations of the poem "Seven Beauties" through the prism of choreographic and scenographic art. The method of research is a semiological analysis, the object of study is the ballet "Seven Beauties", combining the achievements of modern European choreography and medieval Eastern poetry with its inherent imagery, set to the music of Azerbaijani composer Kara Karayev. The composer K. Karayev actively used authentic musical traditions of Azerbaijan (musical harmonies, Ashug melodics and elements of Azerbaijani folk modes), combining them with European melodies and rhythms. Analyzing the film-ballet "Seven Beauties" (1982, directed by Felix Slidovker) and the new production of the Theater of Opera and Ballet named after M.F. Akhundov (2011), the author traces the transformation of the libretto and offers his own rendition of symbolism in the metaphorical work of the classic Nizami Ganjavi. The search for truth, beauty, and justice has always been a part of a thinking person. Eastern poets chanted this search, this long and difficult road to the truth, the ideal world. Court intrigues, the luxury of the palace and the daily life of the common people, nobility, guile and love intertwined in this metaphorical Eastern parable, which formed the basis for several interpretations of the ballet "Seven Beauties". Despite the great degree of conventionality inherent in this genre of stage art, the film ballet is characterized by dramaturgical diversity, organic entwinement of developing storylines, $d y$ namic interrelation of social and lyrical-psychological conflicts. The transformation of the libretto to the ballet "Seven Beauties" testifies to a new, deeper reading, its coming closer to the ideological and philosophical metaphorical concept of the original poem by Nizami Ganjavi, to eternal search for the truth, love and justice sung by the poet with oriental imagery characteristic for him.

\section{References}

1. Bonch-Osmolovskaya E.K. Balety Kara Karaeva "Sem' krasavits» $i$ «Tropoyu groma» [Gara Garaev's Ballets "Seven beauties" and "The path of thunder"]. Moscow, 89 p.

2. Dodkhudoeva L.N. Poemy Nizami v srednevekovoi miniatyurnoi zhivopisi [Nizami's Poems in medieval miniature painting]. Moscow, Nauka Publ., 1985, 310 p.

3. Karagicheva L.V. Kara Karaev [Gara Garayev]. Moscow, 1960, 298 p.

4. Maksov A. $U$ vrat tsarstva [At the gates of the Kingdom]. Liniya [Line]. Zhurnal «Balet» v gazetnom formate, 2011, no. 4-5. Pp. 18-19.

5. Medvedev V.M. Balet Kara Karaeva "Sem' krasavits». Problema traditsii i obnovleniya [Gara Garaev's Ballet "Seven beauties". The problem of tradition and renewal]. Vestnik Akademii russkogo baleta imeni A. Ya. Vaganovoi, 2010, vol. 1(23), pp. 169-175.

6. Temiz Ya. Libretto "Sem' krasavits" [Libretto of "Seven beauties"]. Available at: https://iri-inf-ballet.livejournal.com/167446.html (Accessed 2020, Oct. 5).

7. Fakhradova R. Balet "Sem' krasavits» K. Karaeva [Ballet "Seven beauties" by G. Garaev]. Baku, 1957, 68 p.

FARIDA ALTAI MIR-BAGIRZADE - Ph.D. in Art History, Associate Professor in Aesthetics, Leading Researcher at the Department of Fine, Decorative and Applied Arts and Heraldry, Institute of Architecture and Art of the National Academy of Sciences of Azerbaijan (faridamb2013@gmail.com).

Формат цитирования: Мир-Багирзаде Ф.А. Ориентальная символика балета «Семь красавиц» по мотивам поэмы Низами Гянджеви // Исторический поиск. - 2020. - Т. 1, № 4. - C. 197-201. DOI: 10.47026/27129454-2020-1-4-197-201. 